\title{
Over/writing the Father? Dementia and the National Socialist Past in Tilman Jens's Demenz
}

\section{Introduction: A German life-writing genre of the second generation}

Väterbücher or Väterliteratur (literature or books about fathers) are two established, albeit not unproblematic, terms in German literary history. ${ }^{1}$ They denote a corpus of texts - the publication of which peaked in the late 1970s and early 1980s - from what was then West Germany and Austria. Julian Reidy $(2015,203)$ describes them succinctly as "prose texts with an autobiographical basis, aiming at coming to terms with the past in the microcosm of the family."2 With Jennifer Cameron (2011, 37), we can add: "Protagonists reflect upon their families' relationship to the Nazi era, usually in a narrative of generational conflict between father and son or daughter."3 Authors' "conflict over origins and identity against the background of fascism” (Brandstädter 2010, 284) were what drove the production of this genre. ${ }^{4}$ East German literature of the time did not produce any such Väterliteratur. Ernestine Schlant (1999, 4) explains why: “As a Communist regime, East Germany saw itself ipso facto as inimical to fascism and hence under no obligation to acknowledge its own Nazi past. Fascism was interpreted

1 All translations mine.

2 The original German phrase reads, "autobiographisch gefärbte und auf Vergangenheitsbewältigung im Mikrokosmos der Familie abzielende Prosatexte.” For the sake of readability and with an international readership in mind, I will provide the German phrases in the footnotes only and work with what I hope to be adequate translations of the literature in the main body of the text.

3 These texts often focus on the father figure but the mother, too, is important to many a $V a$ terbuch. Reidy $(2015,204)$ points towards Bernward Vesper's, Peter Härtling's, Günter Seuren's and Brigitte Schwaiger's work. Mothers have also been at the centre of standalone texts (e.g. in writing by Christoph Meckel, Julian Schutting and Helga Schneider). A term to describe mother accounts has not emerged, although Katra A. Byram experiments with Mütterliteratur (mother literature) to highlight the gendered nature of the term Väterliteratur as she sets out to analyse what it distorts. Byram (2018, 42-43) contends, "Gender expectations have screened certain elements of Väterliteratur from widespread perception.”

4 Orig.: "Konflikt um Herkunft und Identität vor dem Hintergrund des Faschismus." 
as an outgrowth of capitalism, and capitalism was still the reigning economic system in West Germany. It hence fell upon West Germany to deal with this past.”

As the authors took to task their fathers or parents, they aimed to address the German public as well as their kin: each example of family history - each microcosm - was meant to speak to the macrocosm that is wider society. Most Väterbücher authors were representatives of the so-called second generation (born c. 1930-1945, in Michael Ostheimer's classification [2013, 173]), that is, the sons and, though less often, also the daughters of the perpetrator / wartime generation (the latter born c. 1900-1925, according to Ostheimer). ${ }^{5}$ Through literary writing, these authors belatedly tried to trace their fathers' or parents' lives and reckon with their ideological convictions as well as the crimes they (might have) committed during the Second World War and the Holocaust. The perpetrator status of the fathers or parents written about differed; their roles ranged from that of high-ranking Nazi officials to collaborators or profiteers to ideological followers of and bystanders to the National Socialist regime.

Historically, the majority of these texts emerged in the wake of the student movement, under the banner of 1968. As the genre turns attention towards the family unit and the home, Ostheimer $(2013,195)$ views it as a forum in which sons and daughters pass moral judgement on their fathers/parents, their own awareness raised by events such as the Eichmann trial (1961) in Jerusalem, the Frankfurt Auschwitz trials (1963-1965) and "the idea of an intergenerational balance sheet of justice." 6 The children criticised their fathers/parents for their (in)actions under Nazism as well as, often, for their post-war silence.

I would argue that, in essence, Väterliteratur is a symptom of the widespread failure to confront the fathers with questions in person, during their lifetime, when a critical, productive and honest conversation about their past under National Socialism would still have been possible - at least in theory. I do not intend to cast blame on the children's generation for this circumstance. Sociopsychologically, it may not be all that surprising that within most German families, such conversations did not take place. Members of the parent generation typically stayed silent, for they were traumatised, conscious of their guilt or showing signs of what psychoanalysis has termed 'derealisation': an inability to bring together the historical events of the Second World War and the Holocaust (their scope) with one's

\footnotetext{
5 Julian Reidy $(2012,13)$ takes authors born in the years of the Nazi dictatorship as well as in the immediate post-war years to be members of the second generation. Mathias Brandstädter (2010, 118-120) is critical of regarding Väterbücher authors as members of one generation. He finds authors' years of birth less relevant than the thematic focus and formal features of their writing.
}

6 Orig.: "die Vorstellung von einer intergenerationellen Gerechtigkeitsbilanz." 
own individual life and actions of those years, thus avoiding feelings of shame, guilt or grief (Lohl 2019; with recourse to Alexander and Margarete Mitscherlich's Inability to Mourn [1967]). In this emotional and social climate, many children were too afraid of what they might find to press their parents on the issue of complicity with much persistence. The psychologist Dan Bar-On $(1989,425)$ termed this "the 'double-wall' phenomenon": "Perpetrators did not want to disclose their inner conflicts, and others - their children, the potential confessors, and maybe most of us - did not want to know about it."

Väterbücher, then, are texts that try to make up for missed conversations or, indeed, confrontations. When authors constructed these accounts, their fathers were typically deceased (Ostheimer 2013, 166), which meant they had to face significant gaps in knowledge about their fathers' pasts and inner lives. These circumstances complicated finding any kind of definite answer to the question that, like Bar-On $(1989,427)$ in his psychological study, these authors too seem to have posed: "did a conflict of morality exist, and did it ever surface" over the course of the years following 1945? In attempts to counter a difficult point of departure, the sons and daughters often turned to archival materials (both from official as well as family collections) before engaging in what could be described as imaginative life writing: filling in the remaining gaps creatively.

What the writing descendant as well as the reading public gains from such creative nonfiction will be one of the overarching questions to bear in mind as we turn our attention to a more contemporary book: the journalist Tilman Jens's 2009 account Demenz: Abschied von meinem Vater (Dementia: A farewell to my father) about his father, renowned scholar and author Walter Jens. ${ }^{7}$ This text, I argue, can be regarded as a new or belated Vaterbuch. While written in a very different era to the genre-defining examples of the 1970s and 1980s, the text's thematic focus as well as a number of its formal - e.g. stylistic - features warrants reading it as such. Crucially, it too emerges from failed and discontinued attempts to talk openly (T. Jens 2009, 65, 73-79). What is furthermore significant is that Tilman Jens writes it at a point in history that sees the last witnesses of the Holocaust and the Second World War dying and the memory of these catastrophic events

7 Gert Ueding (2009) identifies the subtitle as a reference to Peter Weiss' Abschied von den Eltern (1961; Leavetaking). There is an intertextual reference to Weiss's text in the main body of Demenz that corroborates Ueding's association (T. Jens 2009, 34), regardless of the irony that Weiss, as an author of Jewish descent, writes under decidedly different circumstances to Tilman Jens. Additionally, examples of the Väterbücher genre resonate with Demenz's title, as they, too, feature the word Abschied in their titles, e.g. Seuren's Abschied von einem Mörder (Farewell to a murderer; 1980) and Hanns-Josef Ortheil's Abschied von den Kriegsteilnehmern (Farewell to the participants in war; 1992). 
beginning to solidify. I will consider how this influences and motivates his text and the decision to bring together the narration of the father's dementia in old age with details of a youth under National Socialism.

\section{The case of Walter Jens - a moralist with feet of clay}

After studying classical philology and German studies at Hamburg and Freiburg, Walter Jens (born 1923 in Hamburg) became an eminent scholar, translator, author and professor of rhetorics at the Universität Tübingen. A distinguished public intellectual, he was a member of the Gruppe 47 from $1950,{ }^{8}$ president of the then West German PEN Centre from 1976 to 1982 and, as president of the West German Akademie der Künste, he was a major figure in the reunification of the Akademie with its East German equivalent after the fall of the Wall (Seger 2003, 847). Jens corresponded with Ingeborg Bachmann, Ernst Bloch, Heinrich Böll, Willy Brandt, Paul Celan, Günter Grass, Siegfried Lenz, Thomas Mann, George Tabori and many other significant political and literary figures besides (849). Becoming professor emeritus in 1988 (847), he continued to write scholarly books and articles and to engage in public debates. Newspapers and other media channels regularly requested his commentary on sociopolitical and cultural events as well as current affairs.

In November 2003, the Internationales Germanistenlexikon 1800-1950, an authoritative reference work documenting the lives and achievements of influential scholars of German studies was published, including an extensive entry on Walter Jens (Seger 2003; Dunphy 2005). The encyclopaedia's chief editor, Christoph König, had incorporated newly accessible information from the NSDAP (Nationalsozialistische Deutsche Arbeiterpartei) membership register held at Berlin's Federal Archives, and the news broke in the German media that Walter Jens had been a member of the Nazi Party from 1942. ${ }^{9}$ As his son, Tilman Jens $(2009,25)$,

8 The Gruppe 47, named after the year of its foundation, "reestablished a literary community [in Germany] after the Second World War based on explicit principles of candor and commitment to an open society and a literature that reflected that openness, rather than its opposite of abject obedience to state ideology or abstruse evasiveness (as in the literature of Inner Emigration)" (Donahue 2014).

9 Previously held at the Berlin Document Center, created by the US Armed Forces and managed by the United States until 1994 (Fehlauer 2010). For more about the register, the information it held on men who became leading political figures of West Germany, and the slow 
pointedly puts it, the revelation "astonishes some, horrifies many." seemingly detached observer role, the journalist son explains the explosive nature of this revelation about his father, then an 80-year-old man: "Walter Jens, the solitary and loner, courageous naysayer for decades, joined the NSDAP in September 1942 and - this seems to be the sticking point - he remained silent about it for nearly sixty years” (T. Jens 2009, 25). ${ }^{11}$ Making matters worse, Walter Jens publicly announced he could not remember anything. Numerous other literati of the Flakhelfer generation could be listed here who, like Walter Jens, in subsequent years saw themselves confronted with evidence of their Nazi Party membership late in their lives (Martin Walser, Siegfried Lenz, Dieter Wellershoff and Erich Loest among them) and who often reacted similarly (Herwig 2013, Chs. 3, 7). ${ }^{12}$ Arguably, the highest-profile revelation was of Günter Grass in 2006 having been conscripted into the Waffen-SS at age 17, late in 1944 (Pietsch 2006, 360-365; Kölbel 2007; Mews 2008, 334-342; Herwig 2013, Ch. 6).

Contrary to the impression his tone in the above quotation may give, Tilman Jens is of course highly invested in the revelation, both emotionally and intellectually. He highlights that his father loved to assume "the role of the Enlightenment philosopher” (T. Jens 2009, 27, similarly: 60) - a self-stylisation that post-November 2003, the son realises Walter Jens did not consistently live up to. ${ }^{13}$ In the wake of the media reports, a nationalist essay which Walter Jens had published in 1943, then a student of literature, resurfaced, adding to the scandal. In it, he uses Nazi expressions such as "literature of degeneration" (T. Jens 2009, 61). ${ }^{14}$ And although the historian Götz Aly (2004) describes the essay by the then 20-year-old student as marked by völkisch ideas but not as antisemitic, it fuelled the public debate. The impression of the young Walter Jens as a conformist hardened.

negotiations between the US and the FRG about the wider archive's transition into the hands of the German authorities, see Herwig (2013, esp. Chs. 1-3).

10 Orig.: "sorgt bei manchem für Erstaunen, bei vielen für Entsetzen."

11 Orig.: "Walter Jens, Solitär und Einzelgänger, der couragierte Nein-Sager über Jahrzehnte, ist im September 1942 der NSDAP beigetreten und hat darüber, das scheint der Knackpunkt, fast 60 Jahre lang geschwiegen."

12 The military term Flakhelfer translates as 'anti-aircraft helper' or 'gun assistant.' As a generational term, it more broadly describes those who were teenagers in Nazi Germany and indoctrinated from an early age, because a large proportion of the country's male teenage population (especially boys born in the years 1926-1928) were drafted to join the anti-aircraft artillery in the final years of the Second World War.

13 Orig.: "die Rolle des Aufklärers.”

14 Orig.: "Entartungsliteratur." 
The apparent incongruity of his father's reputation as one of the Federal Republic of Germany's "literary intellectuals who had dispensed the lessons of Auschwitz to the nation, long accorded an almost priest-like status on the basis of an apparently unimpeachable moral probity and intellectual integrity" (Niven 2018, 37) and his dubitable behaviour as a young man under Nazism lies at the heart of the journalist's issues with the father figure from that point on and must be understood as a key motivation for his writing Demenz. Although written while his father was still alive, it has much in common with the discoveries and motivations of many of the authors of the original Väterbücher in the 1970s and 1980s. Christoph Meckel, for example, started writing Suchbild (Picture puzzle) upon discovering his then-deceased father's Nazi-era diary, a document which reveals Eberhard Meckel, who was also a writer, to have sympathised with Nazi ideology to a much larger extent than the son previously knew (Meckel 2005 [1980], 179).

\section{Demenz - all about illness?}

Around the time the scandal broke, Walter Jens began to show the first signs of dementia - the illness of which he eventually died in June 2013. As the son describes in his book, the illness was first misdiagnosed as a form of depression, a condition that Walter Jens had suffered from at least once before in his life (T. Jens 2009, 41-43). In the final chapter to her memoir Unvollständige Erinnerungen (Incomplete recollections), published in the same year as Demenz, Tilman Jens's mother, the philologist Inge Jens, ${ }^{15}$ admits that her husband's depression diagnosis did not scare her, that she and her family were in fact clinging to it - for it seemed familiar and manageable - and that even when the doctors eventually did talk about dementia, she did not understand the import of this new, more accurate diagnosis straight away (I. Jens 2009, 272, 275). ${ }^{16}$

With Demenz: Abschied von meinem Vater, it seems that Tilman Jens pursues several aims: the book most obviously, and as indicated by its title, traces

15 A German studies scholar and author in her own right, member of the PEN Centre Germany and editor of the diaries of Thomas Mann, among others.

16 The specific form of dementia he had is described by Inge Jens (2017) as "eine Sonderform der Demenz, eine sogenannte Angiopathie" (a variety of dementia, a so-called angiopathy). She repeatedly uses the term Angiopathie in her 2016 publication Langsames Entschwinden: Vom Leben mit einem Demenzkranken (Slowly fading away: About life with a dementia sufferer), too. Tilman Jens $(2009,42)$ explains in Demenz that it was vascular dementia the father suffered from, with elements of Alzheimer's. 
the story of Walter Jens's dementia, especially the illness's progression and lived reality, and the effect on family dynamics as well as the strain his father's illness puts on his mother. Facing the fact that dementia is a terminal illness, it further explores questions such as what constitutes a good life and a good death. The telling of his story strikes Tilman Jens $(2009,42)$ as important because of the public nature of his father's life and the stigma which forms of dementia, especially Alzheimer's, still carry (perhaps more so at the time of writing than now) - reflected too in the family's and even Walter Jens's doctors' initial denial of the diagnosis. ${ }^{17}$ From this perspective, Walter Jens is a case in point to counter the idea that one's intellect can save a person from developing dementia (T. Jens 2009, 42-43). Tilman Jens $(2009,27)$ draws legitimacy for his public project from the way the father had ultimately overcome his depression in the 1980s, namely "in public, pointed speech," as the son recalls. ${ }^{18}$ Moreover, the author is eager to highlight the fact that by writing and publishing Demenz, he acts in line with his immediate family's wishes. Prominently placed in the book's inside blurb is the declaration: "My mother, my brother and I all agree, we do not want to, we will not hide his suffering."19

Yet even though it is styled to be so, Tilman Jens's Demenz is not merely a negotiation of the illness and its consequences or a text that counters the marginalisation of people with dementia - if it is that at all, since it remains steeped in ableist/disablist language, likely more so than its author was aware. ${ }^{20}$ It is also, and maybe more so, a text that seeks out the cracks in the father's image and one that retrospectively questions the validity of some of his intellectual work, too. It is thus an Abschied (farewell), as the subtitle has it, in at least two senses: the text bids farewell to Walter Jens as a leading intellectual in the view of cognitive decline and memory loss as much as it bids farewell to the dominant father figure as untouchable, morally and ethically, in the light of new knowledge about his past.

Stylistically, in Tilman Jens's writing about the past and the present, about the able academic and the man with dementia, about the former role model and

17 Martina Zimmermann (2017a, 90) explains, "Society sees the core stigma attached to Alzheimer's as centering on the patient's dependence, inertia, and loss of self."

18 Orig.: "in öffentlicher, zugespitzter Rede."

19 Orig.: "Meine Mutter, mein Bruder und ich sind uns einig, wir wollen, wir werden sein Leid nicht verstecken."

20 Compare Tilman Jens's use of mainstream cultural metaphors to do with darkness and shadow, state(s) of sleep or 'living death,' ideas of a return to childhood and the language of descent (T. Jens 2009, 14, 43). For scholarly commentary on this kind of imagery and the damage it does to people living with dementia, see e.g. Zeilig (2013) and Zimmermann (2017a; 2017b). 
the fallen moralist, the son creates a dichotomous image. The extent of the hero's fall could hardly be made clearer. On the one hand, there is "the father I knew"; however, "he is long gone." ${ }^{21}$ On the other hand, Tilman Jens (2009, 140) discovers "a completely different father, a creaturely father." 22 I argue that the split in Tilman Jens's perception or, at least, in the representation of his father 'now' and 'then,' is due both to his father's illness and to the public disclosure of his membership in the Nazi Party. Although this double imagery may be rhetorically convenient when juxtaposing images of a father that do not seem to add up, we may wonder what this type of rhetoric obscures: his father was not replaced by someone else but changed and developed as a person over a lifetime both in terms of his ideological leanings and his attitudes towards dis/ability; lastly, Walter Jens has aged and fallen ill himself.

Trawling through the family archive, Tilman Jens unearths a significant number of recordings of past TV appearances, manuscripts of old speeches and old correspondence. Having access to this private documentation of his father's public thinking, as well as all that Walter Jens had published during his prolific academic and literary career, the controversial statements on Sterbehilfe (assisted dying) Jens senior made when still well trigger the son reviewing the material at a time that he is trying to understand whether Walter Jens's past philosophical opinion on assisted dying holds in practice and should be understood in the sense of an advance directive, a guideline for Inge Jens and her sons. This question is at the centre of Demenz's opening chapter (T. Jens 2009, 5-21) as well as its concluding reflections (128-140) and is reflected in Tilman Jens's choice of epigraph to the book as a whole, too, taken from Walter Jens's joint 1995 publication with the theologian Hans Küng: Menschenwürdig sterben: Ein Plädoyer für Selbstverantwortung (Dying in dignity: A case for self-responsibility). ${ }^{23}$

Tilman Jens quotes a particularly incisive statement his father made during a 1996 interview: "I don't think that someone who does not recognise any of their closest relatives anymore at the end is still a person in the human sense. Which is why I think everyone should be able to decide: at this or that point, I want to be allowed to die." ${ }^{24}$ He reacts with sadness and anger to this incendiary find, as he reports (T. Jens 2009, 13), and critiques the father's detached reasoning on the

21 Orig.: "Der Vater, den ich kannte, der ist lang schon gegangen."

22 Orig.: "einen ganz anderen Vater [. . .], einen kreatürlichen Vater.”

23 Menschenwürdig sterben has been revised and reissued with an additional text by Inge Jens reflecting on her husband's illness in 2009.

24 Orig.: "Ich glaube nicht, dass derjenige, der am Ende niemanden mehr erkennt von seinen nächsten Angehörigen, im Sinne des Humanen noch ein Mensch ist. Und deshalb denke ich sollte jeder bestimmen können, dann und dann möchte ich, dass ich sterben darf.” 
topic in retrospect, exposing its flaws and reading it as the effect of internalised disablism. ${ }^{25}$ It dovetails with Walter Jens's attitudes towards ageing more generally, as expressed in the past: Tilman Jens (8) remembers him casually remarking he would rather be dead than become a wheelchair user or have to face incontinence.

The reader will note that both in the reasons he gives for speaking up about his father's condition in book form and in his view on assisted dying, Tilman Jens rhetorically takes a morally consistent stance that he knew would likely meet with general approval. But when it comes to the concurrence of the onset of Walter Jens's dementia and the uncomfortable late revelation of his opportunism in the 1940s, as evidenced by the uncovered party membership and his student essay, the son seeks to establish a causal connection between the two facts - the onset of illness and the historical revelations - that was perceived to be provocative. It was deemed slanderous, vengeful and bitter - in short, immoral - when Demenz first came out (e.g. Ueding 2009; Radisch 2009).

\section{The son's linking of dementia and the NS past: The convenience of memory loss}

“He doesn't want to talk, he cannot remember. Full stop" (T. Jens 2009, 25); this is how the son summarises Walter Jens's inadequate handling of the historical finds. ${ }^{26}$ Syntactically, through use of parallelism, what is hinted at here is someone vacillating between not wanting and not being able to speak or remember, respectively. A resolute 'full stop' is being put to any attempts to address the matter, highlighting the fathers' resistance. Later in the text, Tilman Jens writes more clearly about his understanding of what is happening to his father: "In the winter months of 2003 / 2004, he resigns. He does not fight the paralysing sadness - his memory deteriorates rapidly. More and more frequently he can't recall terms and names" (91). ${ }^{27}$ He appears to blame the illness, or at least the

25 According to family lore, Walter Jens's mother scolded the young boy from an early age: "Du bist unbeholfen, Du bist ängstlich, Du machst, gebückt durch Deine Asthma-Krankheit, eine schlechte Figur, also musst Du ein Geistesriese werden" (You are clumsy, you are anxious, you are stooped, bent over by your asthma, so you have to become a giant of the mind) (T. Jens 2009, 14).

26 Orig.: "Er [. . .] mag nicht reden, er kann sich nicht erinnern. Punktum." For Walter Jens's handling of the situation, see also Herwig (2013, 105-110).

27 Orig.: "In den Wintermonaten 2003 / 2004 gibt er sich auf. Er kämpft nicht an gegen die lähmende Traurigkeit - sein Gedächtnis verfällt rapide. Immer häufiger fallen ihm Begriffe und Namen nicht ein." 
pace of its progression, on Walter Jens himself, on what the son regards a matter of willpower: "He who wants to forget, who does not want to remember anymore, cuts ties to the past, does not need mnemonics. Nor a desk or books" (92). ${ }^{28}$ Disablist thinking underlies this statement, as it exaggerates the extent to which one can control the course of one's illness, thus making the ill person responsible for their lack of health.

From a patient's advocate perspective, Martina Zimmermann (2017a, 91) therefore problematises the interpretative link Tilman Jens is establishing, questioning its legitimacy: "Jens interprets dementia as a psychosomatic expression of mental distress. But scientific evidence that would justify this perspective continues to be patchy. Regardless, in the light of the condition's chronic, degenerative, and incurable character, such an interpretation appears most unethical."29 Ostheimer (2013, 369), for the same reason, finds Demenz's line of argument to be "bordering on the cynical." 30 From a cultural studies point of view, the crucial question that remains and seems worth exploring nonetheless is why, then, despite this, is the narrative of Walter Jens having made a near-wilful decision to give in to dementia and to forgetting so attractive to Tilman Jens? And why can it be assumed to be plausible to at least part of the readership of Demenz?

For one, Tilman Jens does believe in the validity of the research that points towards psychosomatic factors playing a role in the progression (if not the onset) of dementia. He summarises the medical research he found in support of the bold hypothesis of his first book in the follow-up publication Vatermord: Wider einen Generalverdacht (Patricide: Against a general suspicion) (T. Jens 2010, 130-138), referring - among others - to a 2003 talk by Joachim Bauer, a version of which can be found online (2016). However, Jens is less of an expert in these matters than Zimmermann and may be more inclined to believe in the validity of findings by Bauer and others because he simply cannot accept the timing or the nature of the father's illness to be purely coincidental: "It is hard to believe in mere

28 Orig.: "Wer vergessen will, wer sich nicht mehr erinnern mag, die Verbindungen zur Vergangenheit kappt, der braucht keine Gedächtnisstützen. Und auch keinen Schreibtisch mehr und keine Bücher.” Elsewhere, Tilman Jens $(2009,85,97)$ speculates on the deep shame and fear his father must have felt upon receiving the letter by König first alerting him to the discovery of the filing card confirming his NSDAP membership and requesting a statement.

29 Zimmermann (2017b) voices additional strong criticism of Tilman Jens's book in her monograph The Poetics and Politics of Alzheimer's Disease Life-Writing (see Chapter 3 in particular, elaborating on sons' writing about a parent's dementia from what Zimmermann terms a "carefree" perspective).

30 Orig.: "ans Zynische grenzende Argumentation.” 
contingency, given the striking temporal coincidence" (T. Jens 2010, 130). ${ }^{31}$ This is because the historical significance of Walter Jens's long silence about his party membership looms too large vis-à-vis his public standing - and because, as the historian Ulrike Jureit $(2019,144)$ puts it with regard to the German/European context, after Auschwitz, "forgetting has lost its innocence." 32 In this context, to simply accept forgetting at face value, without inquiry, has become near impossible culturally; processes of forgetting and acts of remembrance are both morally loaded in the contemporary German discourse and will be for the foreseeable future. ${ }^{33}$ Walter Jens's silence is therefore always already suspect. Worse, it is clearly at odds with his professional ethics and antifascist identity as a member of the renowned Gruppe 47. The famous professor becomes yet another case of the leading writers and thinkers of the young Bundesrepublik partaking in the widespread post-war German repression of the past - just like the majority of the German population who lived through the war (T. Jens 2009, 86-91). The shock that reverberates for the journalist son, and which he processes in Demenz, is that the father this son so admired is no exception here, that he shows the same weakness - or pragmatism - as others have in this regard. This collective behaviour - no matter how conscious or not it was, and we can suspect varying degrees of intent - had a regrettable lasting effect, as Tilman Jens $(2009,74)$, speaking here as a representative of later generations and analyst of the situation, stresses: "The raised moral pointing finger of all those who pretended to have been on the right side [of history] from their first breath has stifled many opportunities for fair discourse."34 Against this background, Tilman Jens cannot help but interpret dementia as a wall to hide behind.

Tilman Jens's aversion to the kind of "amnesia" that was displayed in judicial trials post-1945, too, is expressed clearly in the book, particularly as, in most if not all cases, amnesia was used as an excuse, a way out of admitting culpability for war crimes, the "line of defence" $(2009,107)$ of choice. ${ }^{35} \mathrm{He}$ addresses this in the context of relaying the story of Albert Schaich, a childhood neighbour whom the Jens family trusted and whom Tilman Jens describes as

31 Orig.: "an eine reine Zufälligkeit kann ich, angesichts der frappierenden zeitlichen Koinzidenz, schwer glauben.” The question whether stressful life events qualify as a risk factor in developing dementia diseases is being researched by scientists, yet the evidence is deemed inconclusive by e.g. Sundström et al. (2014).

32 Orig.: "Das Vergessen hat seine Unschuld verloren."

33 Which is not to say that German memory culture does not continue to change and develop; see Niven (2018) for more.

34 Orig.: "Der erhobene moralische Zeigefinger all derer, die vorgaben, vom ersten Atemzug an auf der richtigen Seite gewesen zu sein, hat so manchen fairen Diskurs erstickt."

35 Orig.: "Amnesie"; "Verteidigungslinie." 
his "adopted grandfather" (111). ${ }^{36}$ Schaich turned out to have been a staunch Nazi until the very end of the war and stood trial in 1948 for the murder of another local man in April 1945, a prisoner under his watch - facts of which the Jens family were unaware until 1995, when a local newspaper published an article on the historical events. Though the gravity and quality of each man's secret differed considerably, the neighbour's posthumous exposure after a lifetime's silence can be read as having foreshadowed Walter Jens's own later confrontations with the past. Tilman Jens's narrative reconstruction of the neighbour's crime in contrast to his character as he knew him suggests such a perspective when it stresses how his parents tried to keep the newspaper article from him (103) and how Schaich's past came to catch up with him in later life, when this man, too, developed dementia (113-115).

As Walter Jens's firstborn son, a fact he himself emphasises, Tilman Jens (2009, 74) feels "betrayed" by his father; he is convinced "there would have been so many opportunities to talk about the small, if drastic, errors that would later have made the process of reformation so convincing and clear" (63). ${ }^{37}$ Very much like the older generation of Väterbücher authors, ${ }^{38}$ Tilman Jens consequently takes on the role of public prosecutor against the father in Demenzand, to an extent, also the role of judge over this vexed case (a position he shares with his writing's implied readership). The Väterliteratur genre and its "narrator-centered confessional mode" (Byram 2018, 47) lends itself to this perspective. What is more, by writing and publishing Demenz, "the speaking son" (Vedder 2012, 283) supplants the father, who (through illness) falls silent. ${ }^{39}$ The text, therefore, is inextricably linked to the aforementioned idea of the balance sheet of justice between two generations.

36 Orig.: "Wahlgroßvater."

37 Orig.: "betrogen”; "Es hätte so viele Möglichkeiten gegeben, von den kleinen, wenn auch drastischen Irrtümern zu erzählen, die den Prozess der überzeugenden Läuterung später hätten so anschaulich werden lassen.”

38 Tilman Jens was born in 1954, while the authors of the original Väterbücher are around 20 years older: e.g. Meckel was born in 1935, Seuren in 1932, Paul Kersten in 1943, Sigfrid Gauch in 1945, Elisabeth Plessen in 1944.

39 Orig.: “der sprechende Sohn.” Ulrike Vedder makes a similar observation with regard to Jonathan Franzen's essay "My Father’s Brain” (collected in How to Be Alone [2002]), emphasising the son's role as the narrator of the father's story and speculating on how the act of narration while its result is a form of memorialisation - secures the son's (symbolic) survival in the face of the father's forgetting. Carrying this further (and, I would think, possibly too far), many a journalist writing for the review and arts sections of the national newspapers in Germany charged Tilman Jens with literary patricide, a charge so grave that the son felt the need to reply to it with a second book, titled Vatermord (2010). 
My metaphor of Tilman Jens as a kind of 'judge of morality' is flawed, of course, in at least one respect: it suggests the son writes from an objective position, while feelings of betrayal expressed in the book paint a picture of him as very much emotionally involved in the exposé. He describes how, during the phone call with a journalist colleague who leaked the news about his father's NSDAP membership to him early, "I begin to freeze and shake" (T. Jens 2009, 46). ${ }^{40}$ For the rest of the day, he reports a "fear even to call my parents" (49). ${ }^{41}$ And he begins to question his attitude towards the familial past during the Nazi period and his personal failure to uncover the facts sooner, in a self-critical manner that builds on the legacy of the Väterbücher authors of the 1970s and 1980s: "Why did I never want to know more? For example, what my father had meant by suggesting that he was longing for the end of the regime, but that ultimately he had been one who fitted in. I made life easy for myself. Pestering one's parents with uncomfortable questions was something only others had to do" (51). ${ }^{42}$ Another's words echo here: "The mistake I made was to believe them," writes Meckel (2005 [1980], 180) about his parents in the afterword to Suchbild, and further: "Other children had Nazis for parents - I did not" (181). ${ }^{43}$

Reacting to his own shortcomings as well as his father's, Tilman Jens describes his beginning to gather circumstantial evidence against his father from the moment he learns of the existence of the filing card documenting Walter Jens's NSDAP membership. Note that the legal imagery is employed by Tilman Jens $(2009,49)$ himself here, speaking of a "string of evidence" he is constructing. ${ }^{44}$ With this new knowledge, many childhood memories seem suddenly suspicious, as does the fact that Walter Jens was such a good storyteller: "Suddenly, the few but happily repeated stories from his youth seem strangely smooth and unbroken" (50). ${ }^{45}$ This indicator of inauthenticity suggests that Walter Jens, the professional speaker who once prided himself on his excellent memory (the son recalls this in several instances: $13,14,48,58,59)$, may not have been entirely

40 Orig.: "Mir wird kalt, ich beginne zu zittern."

41 Orig.: "Angst, bei meinen Eltern überhaupt nur anzurufen."

42 Orig.: "Warum habe ich niemals genaueres wissen wollen? Zum Beispiel, was mein Vater denn gemeint hat mit der Andeutung, dass er zwar das Ende des Regimes herbeigesehnt hätte, aber eben doch ein Angepasster gewesen sei. Ich habe es mir einfach gemacht. Die eigenen Eltern mit unbequemen Fragen belästigen, das mussten einzig die anderen.”

43 Orig.: "Mein Fehler war es, ihnen geglaubt zu haben"; "Andere Kinder hatten Nazis zu Eltern - ich nicht."

44 Orig.: "Indizienkette."

45 Orig.: "Auf einmal kommen mir die wenigen, aber gern wiederholten Geschichten aus seiner Jugend merkwürdig glatt und ungebrochen vor." 
truthful about his wartime past including when still in good health - or at least selective about which memories he shared.

The fact that this otherwise prolific writer struggled to pen his autobiography also takes on new significance. Therefore, the son quotes Walter Jens, "I realised: you cannot reveal yourself to be the person you are" (T. Jens 2009, 23). ${ }^{46}$ The previously enigmatic statement suddenly makes sombre sense to the writing son in light of recent revelations (28). ${ }^{47}$ So do other instances in which he now finds his father's actions have fallen short of his ethical requirements: when displaying forbearance with the editor and publisher Hans Rößner, PhD in German studies, regarding his astonishing SS past and post-war reinvention as ostensibly leftwing (52-54) or when lying to Inge Jens about the exact moment he found out about the existence of the record of his compromising NSDAP membership (56, 81). The son concludes, "The evidence is damning" (79). ${ }^{48}$

Neil H. Donahue (2014) finds that Tilman Jens in Demenz "conflates the personal and the public, the private and the historical, - though he does so consciously and deliberately in order to measure the former, the personal, against the latter, the public-historical, as his father had always advocated and done, until the moment in question.” Doing so, the son beats Walter Jens at his own game. In Donahue's favourable view, Tilman Jens becomes the praiseworthy successor, employing the tools of analysis, a sharp rhetoric and critical thinking in his assessment of the father's integrity, emerging as the filial apprentice who surpasses his mentor. It is part of what made the book appear provocative at the time of its original publication - yet over/writing the father can also, more neutrally, be regarded as part of the inevitable succession (which is always also a supersession) of the generations.

The image of the father starts to crack as Tilman Jens reviews his father's life and work under a lens. Dramatically and emotionally describing him as the "man of my life" (T. Jens 2009, 46) and as the father who was and who will always remain his "role model" (63-64), he cannot make the different father images pursued in the text match up. ${ }^{49}$ Just like the son's review of a younger Walter Jens's bold interventions in the German Sterbehilfe debate compared to his unclear words in illness (132-133), what is highlighted here is the disjunction between rhetorical theory and real-world practice.

46 Orig.: "Ich merkte, Du kannst Dich als der, der Du bist, nicht zeigen."

47 In contrast, Inge Jens (2009, 264-268) reads Walter Jens's excuses concerning his autobiography entirely in the light of dementia, speculating in her memoir that he must have been more ill in the years 2002 / 2003 than the family was aware.

48 Orig.: "Die Indizien sind erdrückend."

49 Orig.: "Mann meines Lebens"; "Vorbild." 
At the heart of the text, Demenz negotiates a changing father-son relationship and the author's own identity as the famous professor's eldest son in the light of the evidence of new truths that emerged - as well as in the light of the dementia. The eponymous illness figures as both reality and metaphor. On the one hand, there is the lived reality of progressive and ultimately terminal illness and, on the other, the "political dementia" (T. Jens 2009, 87), the "fatal disease of staying silent” (73, similarly: 89), that Tilman Jens 'diagnoses' his father and many of his contemporaries with. ${ }^{50}$ While the latter, at least partly, is self-inflicted, and therefore a regrettable stain on the individual's biography - signifying nowadays a form of "symbolic contamination with the absolute evil" (Assmann 2019, 37) ${ }^{51}$ the former is much less so. It is, therefore, a slippery slope to bring the two together in the way that Tilman Jens does. The author allows himself the provocation, recognises it as such. He is aware, too, of the advantage he has over his father (and his father's generation as a whole), given his safe position at the writer's desk of today: "It is much easier to settle accounts with the despised Nazis from the writing desk than in real life" (T. Jens 2009, 112). ${ }^{52}$

Notably late in the text, Tilman Jens qualifies his superiority with a confession of his own. He writes that he was not able to communicate the medical diagnosis of dementia to his father, as it implied that he would not recover (T. Jens 2009, 119-124). This withholding is likely to strike a contemporary readership as astonishing, a grave offence, because it is the opposite of common practice today (Hitzer 2018). Imagining a conversation in the subjunctive - "would have, could have" Tilman Jens signals regret. ${ }^{53}$ He knows that, together with his mother, ${ }^{54}$ he thus deprived his father of his agency early and of dealing with the facts of his late life

50 Orig.: "politische[] Demenz"; "fatale Schweigekrankheit."

51 Orig.: "symbolische Kontamination mit dem absolut Bösen." Analysing the strong public reaction to Günter Grass's late public confession of having joined the Waffen-SS shortly before the end of the Second World War, Aleida Assmann (2019) points out how the societal and cultural frames of memory (à la Maurice Halbwachs) have shifted since the 1950s - making a membership in the Waffen-SS (in the case of Grass) unspeakable from the 1960s onwards.

52 Orig.: "Am Schreibtisch lässt sich mit den verhassten Nazis weit leichter abrechnen als im wirklichen Leben."

53 Orig.: "Hätte und wäre." Fellow journalist Andreas Wenderoth, author of Ein halber Held (Half a hero), which is an auto/biographical book about his father's dementia (and most comparable, in design, to Arno Geiger's Der alte König in seinem Exil [2011]; The Old King in His Exile), relays in detail a conversation he and his mother have with Horst Wenderoth about the diagnosis (2016, 106-109). It is an example of how Tilman Jens 'could have' informed the father - regardless of any question about the way in which or for how long he might have been able to retain the information.

54 And younger brother, presumably, although from the book itself, it does not become clear to what extent, if at all, Christoph Jens was involved in this decision. 
for himself. "It was not meant to be" (T. Jens 2009, 123) reads as the weakest point made in the text. ${ }^{55}$ It is evidence of another missed conversation within the Jens family - but this time, it is not the father who holds back vital information. Although written with regard to the withheld diagnosis, the culminating sentence of the son's confession, "I too will be silent" (T. Jens 2009, 124), therefore hangs heavy with meaning in the context of both the metaphorical and actual dementia discussed. ${ }^{56}$

\section{Conclusion: Memory politics at a historical junction}

Rereading Demenz ten years after its original publication, a more nuanced assessment of the text seems possible. This essay recognises the problematic aspects of Tilman Jens's portrayal of his father in his state of dementia while at the same time, it acknowledges the relevance of his critique of the Flakhelfer generation's post-war silence and derealisation of the war years, and the effects of this on succeeding generations. Ultimately, at the specific historical junction at which it was written, the story of Walter Jens's individual pathological forgetting comes to stand in for a collective process; dementia, beyond being a reality that is evidently difficult to process for the Jens family, becomes a tempting, for it is a timely, metaphor. It is not without problems that, at their most extreme, lead to Tilman Jens portraying Walter Jens as seeking refuge in dementia, staging the onset of illness as an easy way out of confronting uncomfortable questioning or as a means to avoid a crisis of identity - yet just like the father's behaviour, the son's, too, must be read in context.

As the wartime generation comes to a close, Tilman Jens's 2009 text reflects a set of specific German fears of forgetting as loss, of historical facts or evidence, of 'how it's really been'; Patrick Finney (2017) describes these as deeply felt cultural anxieties about authenticity. Hand in hand with these fears go worries about a neglect or erosion of the collective post-war responsibility to remember, as fully as possible, the history of National Socialism and the Holocaust as we move into a future without direct witnesses, a future in which our memory discourse will have to rely exclusively on mediated history as relayed in, for instance, films and books

55 Orig.: "Es hat nicht sollen sein."

56 Orig.: "Auch ich werde schweigen." 
(including Jens's). Writing against "large-scale forgetting” (T. Jens 2009, 87), ${ }^{57}$ Tilman Jens therefore does collective memory a service when he complicates the picture his father's vocal generation had painted of themselves in the decades after the end of the war and in the face of historical responsibility. He saw unfold what earlier Väterbücher authors could only anticipate and points out the cracks in what over the decades has become, at times, too smooth a story. Almost by the by, and despite its shortcomings, the text Tilman Jens produces thus indicates that new opportunities, too, may arise at the same time that living memory is lost - for what, following Finney (2017, 158), we may want to call “'fuller' historical readings” of the Nazi past. And so, although fraught with anxiety itself, the example of Demenz may actually assuage some of our own contemporary concerns about future interpretations of history and the course remembrance activities will take. It gives us reason to assume that successive generations will continue to hold previous ones to account.

\section{References}

Aly, Götz. “Was wusste Walter Jens?” Zeit Online, 15 January 2004, updated 7 March 2008. https://www.zeit.de/2004/04/W_Jens/komplettansicht (22 August 2019).

Assmann, Aleida. "Die Rolle von Gedächtnisrahmen für die Dynamik von Erinnern und Vergessen." Vergessen: Warum wir nicht alles erinnern. Ed. Jasmin Alley and Kurt Wettengl. Petersberg: Michael Imhof Verlag, 2019. 35-37.

Bar-On, Dan. "Holocaust Perpetrators and Their Children: A Paradoxical Morality." Journal of Humanistic Psychology 29.4 (1989): 424-443.

Bauer, Joachim. "Die Alzheimer-Demenz: Keine Krankheit, die durch eine Einzelursache zu erklären ist." Demenzrisiko.de. Pflegeethik Initiative Deutschland e.V. 17 August 2016. http://demenzrisiko.de/joachim-bauer-neue-aspekte-der-alzheimer-krankheit/ (22 August 2019).

Brandstädter, Mathias. Folgeschäden: Kontext, narrative Strukturen und Verlaufsformen der Väterliteratur 1960 bis 2008. Würzburg: Königshausen und Neumann, 2010.

Byram, Katra A. "The Challenge of Mütterliteratur: Gender, Generation, and the Genres of German Cultural Memory." German Studies Review 41.1 (2018): 41-59.

Cameron, Jennifer. "Categorically Complicit: Generation Discourse in Contemporary German Literature." Constructions of Conflict: Transmitting Memories of the Past in European Historiography, Culture and Media. Ed. Katharina Hall and Kathryn N. Jones. Bern: Peter Lang, 2011. 35-52.

Donahue, Neil H. “The Political Pathology of Amnesia in Postwar Germany: Tilman Jens' Demenz: Abschied von meinem Vater (2009).” Glossen: German Literature and Culture after 1945.

57 Orig.: "Das große Vergessen.” 
Dickinson College, December 2014. http://blogs.dickinson.edu/glossen/archive/mostrecent-issue-glossen-392014/neil-h-donahue/ (22 August 2019).

Dunphy, Graeme. Rev. of Internationales Germanistenlexikon 1800-1950, ed. Christoph König. Modern Language Review 100.2 (2005): 577-579.

Fehlauer, Heinz. "NS-Unterlagen aus dem Berlin Document Center und die Debatte um ehemalige NSDAP-Mitgliedschaften." Historical Social Research 35.3 (2010): 22-35.

Finney, Patrick. "Politics and Technologies of Authenticity: The Second World War at the Close of Living Memory." Rethinking History 21.2 (2017): 154-170.

Franzen, Jonathan. "My Father's Brain." How to Be Alone. New York: Farrar, Straus and Giroux, 2002. 7-38.

Geiger, Arno. Der alte König in seinem Exil. Munich: Hanser, 2011.

Herwig, Malte. Die Flakhelfer: Wie aus Hitlers jüngsten Parteimitgliedern Deutschlands führende Demokraten wurden. Munich: Deutsche Verlags-Anstalt, 2013.

Hitzer, Bettina. "Von der Krankheit wissen: Der Wandel emotionaler Interaktionen zwischen Arzt und Patient." Wissensrelationen: Beiträge und Debatten zum 2. Sektionskongress der Wissenssoziologie. Ed. Michaela Pfadenhauer and Angelika Poferl. Weinheim: Beltz Juventa, 2018. 55-67.

Jens, Inge. Unvollständige Erinnerungen. Reinbek bei Hamburg: Rowohlt, 2009.

Jens, Inge. Langsames Entschwinden: Vom Leben mit einem Demenzkranken. Reinbek bei Hamburg: Rowohlt, 2016.

Jens, Inge. “Im Krankenhaus wäre Walter verhungert.” Zeit Online, 25 August 2017, updated 28 August 2017. https://www.zeit.de/2017/35/demenz-pflege-heim-inge-jens (22 August 2019).

Jens, Tilman. Demenz. Gütersloh: Gütersloher Verlagshaus, 2009.

Jens, Tilman. Vatermord: Wider einen Generalverdacht. Gütersloh: Gütersloher Verlagshaus, 2010.

Jens, Walter, and Hans Küng. Menschenwürdig sterben: Ein Plädoyer für Selbstverantwortung. 1995. Munich: Piper, 2009.

Jureit, Ulrike. "Vergessen als kulturelle Praxis." Vergessen: Warum wir nicht alles erinnern. Ed. Jasmin Alley and Kurt Wettengl. Petersberg: Michael Imhof Verlag, 2019. 142-144.

Kölbel, Martin. Ed. Ein Buch, ein Bekenntnis: Die Debatte um Günter Grass' “Beim Häuten der Zwiebel." Göttingen: Steidl, 2007.

Lohl, Jan. "Derealisierung der Vergangenheit: Die NS-Volksgemeinschaft nach 1945." Vergessen: Warum wir nicht alles erinnern. Ed. Jasmin Alley and Kurt Wettengl. Petersberg: Michael Imhof Verlag, 2019.149-150.

Meckel, Christoph. Suchbild: Über meinen Vater. 1980. Frankfurt am Main: Fischer Taschenbuch Verlag, 2005.

Mews, Siegfried. Günter Grass and His Critics: From "The Tin Drum" to "Crabwalk." Rochester, NY: Camden House, 2008.

Niven, Bill. "Generation War and Post-didactic Memory: The Nazi Past in Contemporary Germany." Remembering the Second World War. Ed. Patrick Finney. London: Routledge, 2018. 30-45.

Ostheimer, Michael. Ungebetene Hinterlassenschaften: Zur literarischen Imagination über das familiäre Nachleben des Nationalsozialismus. Göttingen: V\&R unipress, 2013.

Pietsch, Timm Niklas. “Wer hört noch zu?" Günter Grass als politischer Redner und Essayist. Essen: Klartext, 2006. 
Radisch, Iris. "Der Mann seines Lebens: Tilman Jens verklärt und denunziert seinen an Demenz erkrankten wehrlosen Vater Walter Jens.” Zeit Online, 19 February 2009. https://www. zeit.de/2009/09/L-Jens (26 August 2019).

Reidy, Julian. Vergessen, was Eltern sind: Relektüre und literaturgeschichtliche Neusituierung der angeblichen Väterliteratur. Göttingen: V\&R unipress, 2012.

Reidy, Julian. "Väterliteratur." Lexikon der Vergangenheitsbewältigung in Deutschland. Ed. Torben Fischer and Matthias N. Lorenz. 3rd ed. Bielefeld: Transcript, 2015.

Schlant, Ernestine. The Language of Silence: West German Literature and the Holocaust. New York: Routledge, 1999.

Seger, Daniel Tobias. “Jens, Walter.” Internationales Germanistenlexikon 1800-1950. Ed. Christoph König. Berlin: De Gruyter, 2003.

Sundström, Anna, Michael Rönnlund, Rolf Adolfsson and Lars-Göran Nilsson. "Stressful Life Events Are Not Associated with the Development of Dementia." International Psychogeriatrics 26.1 (2014): 147-54.

Ueding, Gert. “Tilman Jens begräbt den lebenden Vater.” Welt.de, 18 February 2009. https://www.welt.de/kultur/article3220547/Tilman-Jens-begraebt-den-lebenden-Vater. html (28 August 2019).

Vedder, Ulrike. "Erzählen vom Zerfall: Demenz und Alzheimer in der Gegenwartsliteratur." Zeitschrift für Germanistik 22.2 (2012): 274-289.

Weiss, Peter. Abschied von den Eltern. Frankfurt am Main: Suhrkamp, 1961.

Wenderoth, Andreas. Ein halber Held: Mein Vater und das Vergessen. Munich: Blessing, 2016. Zeilig, Hannah. "Dementia as a Cultural Metaphor.” Gerontologist 54.2 (2013): 258-267.

Zimmermann, Martina. "Alzheimer's Disease Metaphors as Mirror and Lens to the Stigma of Dementia." Literature and Medicine 35.1 (2017a): 71-97.

Zimmermann, Martina. The Poetics and Politics of Alzheimer's Disease Life-Writing. Basingstoke: Palgrave, 2017b. 
